\title{
Current Trends of Investment Effect on Land-Use Practices of Ethiopia
}

\author{
Molla Mekonnen Alemu \\ University of Leicester, Leicester, England \\ Email: mollamekonnen@gmail.com
}

How to cite this paper: Alemu, M.M. (2017) Current Trends of Investment Effect on Land-Use Practices of Ethiopia. Open Access Library Journal, 4: e3326. http://dx.doi.org/10.4236/oalib.1103326

Received: December 23, 2016

Accepted: January 9, 2017

Published: January 12, 2017

Copyright $\odot 2017$ by author and Open Access Library Inc.

This work is licensed under the Creative Commons Attribution International License (CC BY 4.0).

http://creativecommons.org/licenses/by/4.0/

\begin{abstract}
Ethiopia's economy and the livelihoods of its population are highly dependent on agriculture. In spite of the long history of agricultural practice in the country, the sector is still in its traditional subsistence form while the country would have benefitted a lot in transforming the lives of many given the country's endowment with immense natural resources. Vast and fertile lands, availability of water bodies and the varied agro-ecological suitability could have an impact in securing food at household and national levels. As compared to the earlier times, agricultural production and productivity have showed vast improvement. However, weak market linkages, environmental degradation, land tenure insecurity, increased cost of agricultural inputs, climate change, low level of awareness and other factors are still weakening the performance of the sector. Mechanized plant and animal production, agroprocessing, manufacturing, mining, green energy and tourism can be mentioned as the prominent agricultural investment opportunities in the country. As a result of the present Government plan to attract investors, many foreign and local farms and processing industries are popping up in different corners of the country. This paper is, therefore, aimed at assessing the impacts of the current trend of investment on the land-use practices of the country. Literature, reports and observations were used for the compilation of the paper. The findings of the study showed that, many of the ecological and economically valued land resources are being degraded and polluted by the current trends of the investment ventures. The deleterious and negative ecological impacts of the current investment developments from floriculture, tannery and ash producing industries can be mentioned as an example where environmental impact, sustainable use of land resources and land capability issues have not been considered substantially. If not addressed, this may cause for the improper functioning of land resources and the ecosystem services. Therefore, for the actual realization of the intended investment related benefits; thorough review of existing policies and strategies, ensuring the efficient coordinated
\end{abstract}


functioning of concerned institutions and the creation of a proper land-use planning and management instruments need to be considered if the land resources of the country have to be saved from the negative impacts of the current trends of investment.

\section{Subject Areas}

Environmental Economics, Marketing

\section{Keywords}

Agriculture, Land-Use, Investment, Ethiopia

\section{Introduction}

The transformation of the rural and agricultural sectors is fundamental for the development of many African countries in general and Ethiopia in particular. This mainly because of the fact that, in Ethiopia for instance, the agricultural sector supports the livelihoods of more than $80 \%$ of the country's population. The sector also generates more than $90 \%$ of the country's foreign exchange earnings and accounts $43 \%$ of the GDP. Hence, the economy is highly reliant on the growth and development of the agricultural sector [1] [2].

Ethiopia is endowed with ample natural resources such as fertile soil, water resources, favourable climate for the production of different plant and animal species. However, many of the Ethiopian farmers are still practicing the traditional rainfed agriculture while production maximization could have been achieved through improved irrigation developments, agroforestry practices, soil and water conservation, improved agronomic practices and by diversifying the production system.

Many of the development practitioners largely agree as the root cause of the smallholders agriculture underdevelopment is mainly related to technical capabilities. This outlook also recognizes low level of agricultural productivity as the major bottle neck of the sector and suggests finding alternative solutions will help to alleviate the problem. The current agricultural system of the country is still not in a position of maximizing agricultural production and productivity through the national agricultural extension programmes. Apart from that, bridging the gaps that entail between the current unecological development of investment venture and the lack of area specific technologies is an agenda that is yet to be addressed [3].

The formulation of the Agricultural Development Lead Industrialization strategy of Ethiopia was believed to kick-start the transformation of the sector. In fact, the previous Governments of Ethiopia in the 1960s and 70s have also tried to increase the productivity of the sector (Bansal et al., 2011) cited in [4]. The agricultural sector, however, is still crawling with its subsistence and low productivity nature as a result of the low levels of improved technologies utiliza- 
tion. The Growth and Transformation Development Programme and other development strategies of the country have emphasized the centrality of the green economy development for the transformation of the nation and this will require transforming the production systems through improved land-use policy and strategic actions and improving access to developmental inputs namely improved seeds, credit services and others [4].

The achievements in the agricultural development have showed as transformation of the sector is possible. Foreign and local investments in the sector are also hugely impacting the development of the sector. However, these investment endeavors also have their own impact on the sustainable development and management of the environmental resources. Hence, the creation of the enabling environment in terms of policy, establishment and strengthening of efficient institutional systems and structures, environmental and social impact considerations merits a proper follow up so as to make a sustained developmental change of the sector. This paper is, therefore, intended to assess the status, prospects and constraints of the current trend of investment on agricultural land use in Ethiopia.

The major objectives of the article are to characterize Ethiopia's current trend of investment on agricultural land use assess the key challenges and constraints of agricultural land use in line with the current trend of investment; and recommend way forwards for sustained utilization of land.

\section{Methodology}

\subsection{Country Context}

Located in East Africa, Ethiopia is an ancient country with a lot of historical sites. Geographically, Ethiopia is at the crossways among Middle East and Africa and hence, throughout its ancient and long history, it has been a melting pot for a wide range of traditions as well as cultural set ups. As a result, the country owns a complex range of nations and nationalities, ethnic and linguistic diversity. The country shares borders with the Republic of Southern Sudan, Kenya, Djibouti, Eritrea, the Republic of Sudan, and Somalia [5].

Ethiopia has varied geographical forms ranging from the Ras Dashen peaks of $4550 \mathrm{~m}$ above sea level, to the 110 meters below sea level Afar Depressions. Temperatures also range from 47 degrees Celsius in the Afar Depression to as low as 10 degrees Celsius in the highlands of the country. The country's total area of land is about 1.1 million $\mathrm{Km}^{2}$ [6].

Climatologically, the country has three different categories: dry, tropical rainy and warm temperate. The average maximum and minimum temperatures differ from region to region and the across the seasons of the year. The highest temperatures are from March to May while the lowest temperatures are from November to December. The westerly and the south-easterly winds are the one influencing the country's mean annual distribution of rainfall. The overall distribution of the annual rainfall is seasonal which again varies in intensity, amount, coverage, and time as it moves from the southwest to the northeast [7].

Ethiopia has a great potential for irrigation agriculture, like any other sub- 
Sahara African countries, however, the country is yet to utilize those resources in an efficient and productive way. The country is estimated to have a water storage capacity of 38 cubic metres of water per person hence; improved water management can help to enhance food security endeavors [8].

\subsection{Data Collection and Analysis}

Cognizant of the current enhanced trend of foreign and local investments in Ethiopia, the article endeavored to summarize the basic land-use related challenges, threats and set basic principles as a way forward for the sustainable utilization of the natural capitals of the country in an environment friendly way. For the compilation of this article, different sources of information, such as journals, books, proceedings and reports were reviewed as sources of information. Field level ground truthing was also used to substantiate the review of this article.

\section{Investment in Ethiopia}

According to the Ethiopian Investment Commission [9], Ethiopia follows a market oriented economic development strategy. For the realization of this motto, the Government has issued a liberalized investment code and established the Commission and Regional Investment bureaus. The commission is established to provide a one-stop investment service such as the provision of trade registration and operating licenses for private investors, granting of work permits to expatriate employees and facilitating the acquisition of land as well as utilities by private investors.

Accordingly, different investment opportunities which have created local and regional economic development are being managed by foreign and local private investors. The sectors include, agriculture (food Crops, beverage crops, cotton and Sugar, horticulture, livestock, fishery, forestry and agricultural Services), manufacturing, tannery and leather goods and articles, textile, glass and ceramics, chemicals and chemical products, drugs and pharmaceuticals, paper and paper products, plastic products, building materials, electrical and electronic products, metallurgy, machinery and equipment, mining, tourism, etc. (Figure 1). Since all these different ventures require a substantial amount of land and its related resources, if not properly implemented, these investment activities will have a direct and indirect impact on the environment, ecosystems and the services they provide (Table 1 ).

\section{Land Tenure}

Land is the most extensively used natural resource in agriculture and other forms of investment. The availability and productivity of land resources is, however, being challenged by the ever increasing population pressure. Deforestation, inadequate soil and water conservation practices, land degradation, environmental pollution, and climate change are also contributing for the degradation of land resources. The smallholder subsistence agriculture also contributes 
Table 1. Ethiopia's top ten export commodities (2000-2011) [11].

\begin{tabular}{|c|c|c|c|c|c|c|c|c|c|c|c|c|c|c|}
\hline \multirow{2}{*}{$\begin{array}{l}\text { The top ten } \\
\text { exported items } \\
\text { (consolidated) }\end{array}$} & \multicolumn{12}{|c|}{ FOB values (in million US\$) } & \multirow{2}{*}{$\begin{array}{c}\text { All } \\
\text { years } \\
\text { total }\end{array}$} & \multirow{2}{*}{$\begin{array}{c}\% \\
\text { of all } \\
\text { years }\end{array}$} \\
\hline & 2000 & 2001 & 2002 & 2003 & 2004 & 2005 & 2006 & 2007 & 2008 & 2009 & 2010 & 2011 & & \\
\hline $\begin{array}{c}\text { All } \\
\text { products-total export }\end{array}$ & 482 & 453 & 473 & 580 & 615 & 897 & 999 & 1183 & 1543 & 1493 & 2147 & 2543 & 13408 & $100 \%$ \\
\hline $\begin{array}{c}\text { Coffee, not roasted } \\
\text { or decaffeinated }\end{array}$ & 255 & 150 & 167 & 181 & 244 & 353 & 427 & 408 & 551 & 361 & 676 & 836 & 4608 & $34.3 \%$ \\
\hline Sesamum seeds & 22.1 & 26 & 32 & 47.9 & 62.9 & 154 & 116 & 131 & 209 & 327 & 294 & 346 & 1767 & $13.1 \%$ \\
\hline $\begin{array}{c}\text { Semi-manufactured gold } \\
\text { (incl. Gold plated with platinum), } \\
\text { non-monetary }\end{array}$ & 27.7 & 35 & 38 & 7.8 & 79.4 & 44 & 51 & 50.6 & 79.4 & 90.5 & 177 & 123 & 803 & $5.99 \%$ \\
\hline -Fresh chat & 0 & 0 & 0 & 0 & 0 & 0 & 0 & 0 & 87 & 170 & 239 & 162 & 658 & $4.91 \%$ \\
\hline Vegetable products & 68.9 & 54 & 43 & 159 & 6.2 & 67.5 & 86 & 105 & 30 & 0 & 0 & 0 & 619 & $4.62 \%$ \\
\hline -Roses & 0 & 0 & 0 & 0 & 0 & 0 & 0 & 0 & 96.1 & 129 & 137 & 152 & 514 & $3.83 \%$ \\
\hline $\begin{array}{l}\text { Dried kidney beans, incl. } \\
\text { White pea beans, shelled }\end{array}$ & 8.6 & 10 & 14 & 9.7 & 18 & 17.9 & 19 & 34.7 & 42.1 & 40.4 & 43.6 & 63.2 & 321 & $2.40 \%$ \\
\hline$-O X$ & 0 & 0 & 0 & 0 & 0 & 0 & 0 & 0 & 20.7 & 35.9 & 75 & 136 & 268 & $2.00 \%$ \\
\hline $\begin{array}{l}\text { Other oil seeds } \\
\text { and oleaginous fruits }\end{array}$ & 6.4 & 14 & 8.7 & 12.3 & 21 & 17.2 & 7.9 & 19.6 & 39.8 & 44.1 & 34.4 & 13.5 & 239 & $1.78 \%$ \\
\hline Dried chickpeas, shelled & 0 & 10 & 17 & 0.8 & 1.2 & 2 & 11 & 24.9 & 27.8 & 18.2 & 29.3 & 34.7 & 177 & $1.32 \%$ \\
\hline
\end{tabular}
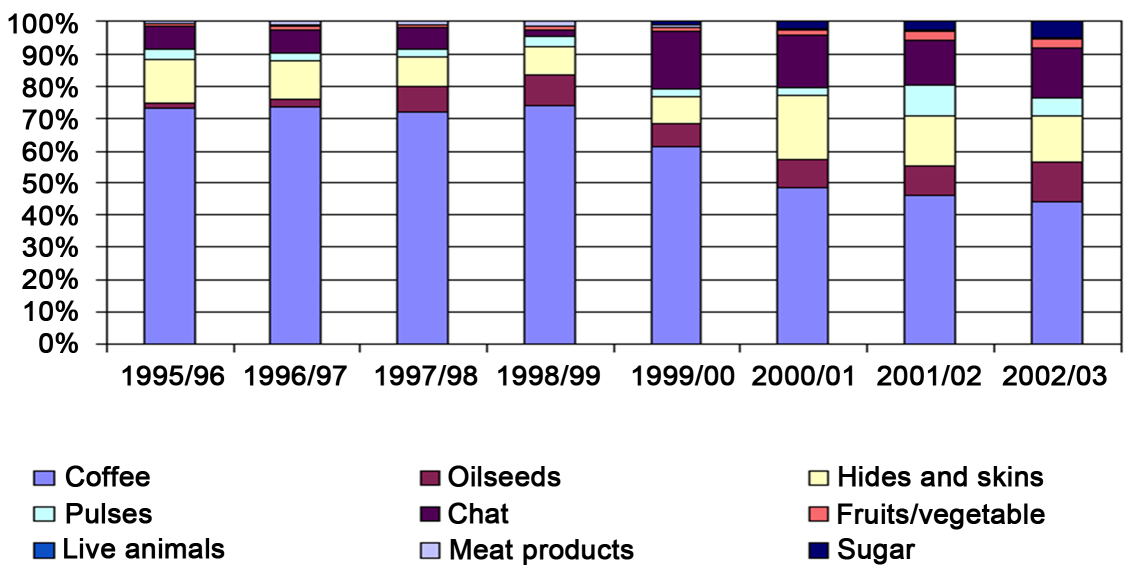

Figure 1. Trends in commodity shares of export values [10].

to this degradation as a result of the low level of awareness and capacity on landuse and land management practices.

In Ethiopia, land is a public property that is being administered by the Government for decades. Farmers have open-ended use right to agricultural land and restricted right to transfer or lease their use right. Own-holding resulting from inheritance and/or official land allocation, cash renting and sharecropping are the main agricultural land tenure systems of the country. In many of the developing countries, insecure land tenure systems of such type is believed to discourage longer term investments and commitment towards proper land management practices as it undermines the value of land ownership feeling in one 
way or another. The users may not have the ownership feeling since they know as the land doesn't belong to them [3].

\section{Land-Use Planning as a Necessity}

Humans have altered the natural ecosystems of the world as a result of land-use and land cover changes. This has been caused by the alarmingly increasing number of the world population. It is also worthy to note that, a substantial amount of land is being covered by massive buildings and other infrastructural developments. A significant proportion of land resources are also put under 'investment' ventures which are putting this precious capital at a high risk of environmental sustainability, the use of chemicals being the prime hazard to nature.

In many cases, it is not uncommon to see land use decisions being based on immediate economic and other related benefits, without considering the future and longer term impacts on the present and the generations to come. Each piece of land has its own capability to support different human activities since it will have its own make in a given locality. Land is a non-renewable resource, once used for building infrastructure or once used for large scale agricultural investments, it is impossible to bring it back to its natural functions that have supported the survival of living things. Hence, this makes proper land use planning not to be a choice, but a necessity that policy and decision makers should always consider critically.

For the materialization of land-use planning Enger [12] has also outlined the below guiding principles which could be considered in the context of countries like Ethiopia:

1) Evaluate and record any unique geologic, geographic, or biologic features of the land; some land has unique features that should be preserved because of their special value to society. National Parks and many wilderness areas have been set aside to preserve unique physical structures scenic characteristics, special ecosystems, or unusual organisms. On a more local level, a stream may provide fishing opportunities near a city or land may have excellent agricultural potential that should take precedence over other uses.

2) Preserve unique cultural or historical feature; some portions of the landscape, areas within cities, and structures have important cultural, historic, or religious importance that should not be compromised by land use decisions.

3) Conserve open space and environmental feature; it must be recognized that open space and natural areas are not unused, low value areas. Therefore, it makes sense to protect open space within and near centers of population.

4) Plan for a variety of transportation options.

\section{Threats of the Current Investment Trend on Agricultural Land-Use}

\subsection{Floriculture in Ethiopia}

Coffee has been Ethiopia's major foreign exchange earner for many years. The smell of the booming floriculture industry, however, is also expanding and con- 
tributing tremendous impacts on the economy of the country. The country is currently the second exporter of flowers in the African context, next to Kenya. The country's agricultural development led industrialization strategy is designed to enhance the commercialization of the smallholder's agriculture and basing the foundations based on the agro-ecological advantages of the country [13].

Floriculture development in Ethiopia dates back to 1981/82. Enhanced by the current Government of Ethiopia the area which was brought under flower production increased from 519 ha in 2005/06 to 2000 ha in 2009/10. With regards to employment opportunities generation, the policy objective was to boost the number of jobs from 21,000 in 2005 (64.4\% female workers) to a total of 70,000 in 2009/10. About 83 local and foreign companies are engaged in the floriculture development industry. The country's foreign exchange earnings from the sector is also increasing from time to time and in the 2013/14 budget year it reached \$245 million [14] [15].

As a result of the infrastructural facilities and ease access to Bole International Airport, most of the production sites are situated around Addis at an altitude of around 2000 masl. There are also others located in the Upper Awash valley and Lake Ziway area 1200 to 1700 masl. The Ethiopian highlands have also provided a favorable climate for the production of roses [15].

Contrary to this, however, the industry is known to have a devastating effect on the environment as a result of the high amount of artillery of toxic fertilizers, insecticides and fungicides in the flower production greenhouses in order to protect the flowers from pests, fungus and all sorts of pressures that affect their crops. For instance, it is known that, some of the companies also came to Ethiopia after they have been evicted from Kenya for their devastating effect on the ecology of Lake Naivasha. Many environmental advocates also showed they concern as the environmental standards are not being implemented by many of the flower producing companies [16] [17]. A study done on the sector in Colombia also showed that, though the industry provided jobs, the economic gains are coming at the expense of the workers and health of the environment which has to be managed in a sustainable and environment friendly way [18].

It is also noted as the different equipments (sprayers, hoses, etc.) may not be cleaned properly as there are instances where these equipments are being cleaned in natural water bodies which in turn pollute rivers and streams which are being used for other purposes by many of the inhabitants in the course of these water bodies. Some carcinogenic chemicals (that can potentially cause cancer) such as flucythrinate, chlorothalonil, cypro-conolone, folpet and mancozeb are also used in the floriculture industry of Ethiopia [19] [20].

The increased usage of fertilizers and other pesticide chemical is also hazardous to the soil since these chemicals normally contain Phosphoric and Sulfuric acids which can increase acidity of the soil which in turn can cause for the eradication of soil microorganisms which will help in recycling nutrients to support life forms in one way or another. This can result in the sterilization of land resources and ecosystem services if the present production way and system of the 
sector is allowed to continue in its hazardous nature to the environment and the wellbeing of its workers. A study conducted in Amhara Regional State showed as the horticulture industry is also causing soil pollution [21].

\subsection{Loss of Farmland}

The major portion of the present day heavy settlement areas were once either covered by forests or has been used as a farmland. The increased density of human population is over exploiting the non-renewable land resources and ecosystems. Areas that has supported ecologically important functions are not covered by concrete roads, massive settlements, gigantic shopping malls, industries, hotels and many more. If we take the case of Kaliti and Akaki area of Addis Ababa the farmlands are now turned to industrial zones. Whilst development is a mandatory venture, efficient ways of land-use should have been deployed in order to save natural habitats that ensure the healthy wellbeing of humanity on the face of earth.

Currently, this trend in Ethiopia also declined the agricultural production potentials and has also a tremendous effect on the loss of natural habitats for the wildlife resources of the country. Rahmato [22] has also mentioned as "there have been at least two notable cases, one in Gambella and the other in the east of Oromia, where land inside a formally designated national park, protected area and wildlife sanctuary was given to investors. The enclosure of the land, vegetation clearing and farm operation has had, or will soon have, a damaging impact on land resources, wildlife, biodiversity, water sources and the natural environment".

The unregulated commercial land resources exploitation by the investors is causing the depletion of soil and its related nutrients. Top soil (the medium for the growth of plants) is now eroding faster than its formations. Poor irrigation practices in the vast arid areas could also easily cause salinization and abandoning of the land resources. The over exploitation of biologically active resources like rivers, can result in the extinction of ecologically important marine organisms.

As the prime aim of profit making investment companies is to maximize their profit margin, they are using heavy agricultural machineries which can easily compact the soil and cause for the creation of soil pan that will cause for the loss of micro pores and modification of the soil texture and structure. This phenomenon will deter the microbial action with in the soil and will also cause for poor infiltration thereof creating conducive condition for the removal of the top soil from the land surface. Apart from this, the compaction can also cause for water to be logged in an area and affect the growth and development of plants. On the other dimension, the logged water can also be a breeding ground for rampant mosquitoes that can cause malaria and other diseases for humans.

\subsection{Deforestation}

Deforestation has wiped of many of the earth's biodiversity in to extinct. It also 
cased for the ill functioning of ecosystems and the services they provide. Deforestation has exacerbated the effects of climate change and global warming to pose a sever threat on the survival and wellbeing of humanity on the face of the earth. Different natural habitats were cleared to meet the ever increasing needs of humanity at the expense of the generations to come.

The annual rate of deforestation in Ethiopia is estimated to be 141,000 hectares. The environmental protection policy of the country also estimates that deforestation rates of the country could reach as high as 200,000 hectares per annum [23]. Population growth, recently booming investment ventures, increase in infrastructural developments, increased energy demand, forest fire, etc. are the major factors that aggravated deforestation on the country's plant genetic resources [24].

In the early 1950 s about $16 \%$ of the total land mass was covered by forests, this percentage has been reduced to less than $3.8 \%$ in the early 1980 s and only $2.7 \%$ or less since 1989 [25] [26]. These days the remaining amount has further dropped down due to the ever increasing rate of population which depends on forest resources for fuel wood, construction materials and other associated uses [27], causing a severe degradation to the ecology as well as socio-economic benefits [28]. Apart from this the country has a total of 120 threatened endemic plant species [24]. Protected areas, which are meant to conserve nature and its genetic resources are also being threatened since economic ambition is overriding the ecological functions of these precious resources. As a result of this, many of the valuable land resources which have got regional and global ecological importance are being destroyed from the face of the earth as they are not being valued for their role as nature's genetic reservoirs of the world's biological resources [29].

In the present day large scale investment sites of Ethiopia, it is not uncommon to see forest resources being cleared for ease of production, charcoal making and infrastructural developments. The would be community conservation area (buffer zone) found on the eastern side of NechSar National Park, that was given to a foreign investor is an example for this.

Land-use and land-cover changes such as deforestation and forest fires for the expansion and development of agricultural land will alter the service of ecosystems and induce the release of carbon dioxide, methane, carbon monoxide, and aerosols to the atmosphere which aggravates climate change and global warming effects. Deforestation also alters the reflectivity capacity of the land surface which in turn governs how much of the sun's energy is absorbed and thus available in the form of heat, while vegetation transpiration and surface hydrology determine how this energy is partitioned into latent and sensible heat fluxes. At the same time, vegetation and urban structure also regulate surface roughness and hence air momentum and heat transport within a given ecological setup [30].

Hence, conservation and maintenance of the remaining vegetation cover from deforestation are some of the vital issues that which need to be addressed by de- 
cision makers if the remaining land resources are to be conserved and used in an integrated and sustainable manner.

\subsection{Water Pollution}

Ironically, poorly managed agricultural practices are the very causes of water pollution. Sedimentation, animal wastes, pesticides, fertilizers can easily be washed and get leached in to water bodies, the ground water table and pollute water resources. This pollution affects biological activities in water bodies. The once breeding grounds of fish and other amphibians can be silted up and causes in reduction as well as loss of biodiversity resources. The roots of plants can also be damaged as a result of water pollution by different chemicals. Car washing activities on riverside will also let oil, grease, coolant and other chemicals to spoil water bodies.

The leather production sector of Ethiopia also contributes a lot for the pollution of different aquatic ecosystems of the country. Studies have shown that, the major portion of leather processing industries of the country lack proper waste purification methods. Since leather processing involves soaking, fleshing, washing, etc. to remove dirt, flesh, salt and other foreign substances which has to be removed by making use of water. As a result of these processes salt, pesticides, flesh, hair, suspended solids, sulfate, ammonia, base, chloride for tanning process (chrome tanning), BOD (Biological Oxygen Demand), COD (Chemical Oxygen Demand), salt, acid, chromium, etc. will be released in to the surrounding water bodies. As a result of this Akaki, Awash, Modjo, etc. rivers of the country are being polluted by the tannery sector by posing a serious health complications along with environmental pollution which includes contamination of underground water, soils and food resources [31] [32] [33].

\subsection{Environmental Disturbances}

Inorganic agricultural production systems involve the use of chemicals and fertilizers so as to maximize production. Pesticides will also be applied to protect the produce from pest and disease. The pesticides don't differentiate useful insects from the harmful ones as they kill them altogether. In this ecological obliteration process other new alien species could arise and invade the area by displacing the native species.

The other dark side of chemicals usage causes for the loss pf useful insets like bees and birds which normally are considered agents of pollination and plant production. Apart from this, as a result of toxicity which will be created in the environment, the extended use of pesticides will result in the loss of farm animal, fish losses, honey bee losses and impact the community through public health concerns.

\section{The Way Forward}

\subsection{Improved Policy and Strategy Implementation}

Although the Government has attractive investment policies and approaches, the 
enforcement of environmental due considerations are still lagging behind. As a result of this precious natural ecosystems are being lost in a non-reverse way. As for instance, according to Article 7.2 of the Fish Resources Management, Development and Control Proclamation No. 78/2004 and Regulation No. 62/99 of the Southern Nations and Nationalities Peoples Regional State any farming activities are strictly prohibited within $1 \mathrm{~km}$ radius of a water body [34]. This decision was brilliantly aimed at having a buffer zone to protect aquatic ecosystems from human interference. However, presently the writer has physically witnessed investment activities being held in less than 10 meters from the shorelines of Lake Chamo. As a result of this and other anthropogenic activities, research findings showed that, the size of the Lake is shrinking dramatically from time to time [35].

Hence, this clearly suggests the importance of an effective policy and strategy implementation follow-up system by placing a proper structure of check and balance and separation of powers among the several branches of government authorities and political administrative bodies. The development and inaction of environmental damage accountability modalities with improved judiciary arrangements is also an issue which the decision and policy makers have to consider.

In the country, it is not uncommon to see fragmented investment related decisions which will have short and longer term impact on the sustainable development efforts of the country. Inter-agency coordination and consultations are still under criticism. When hundreds of thousands hectares were given to foreign investors from the ecologically important resources of Gambella National Park or the Babile Elephant Sanctuary, the Ethiopian Wildlife Conservation Authority (EWCA) was not aware, while it is the concerned Governmental agency for the management and administration of National Parks, Sanctuaries and Game Reserves of the country [22]. Thus, more importantly, the lack of harmonized/joint efforts among government institutions in environmental development and protection endeavors needs to be addressed as at most urgency.

\subsection{Land Tenure Security}

Land tenure security is an important policy instrument that can enhance the sustainable development and management of land resources. In the case of Ethiopia, however, land is considered as a public property and this could create undesirable relationship between the smallholders and the natural capitals of the country. This will also undermine the value and the ownership feeling which in turn halt longer-term investments on land resources. In many developing countries, it is believed as land tenure insecurity to inhibit the community from recognizing the economic and other welfares which are directly linked to secure property rights on land [3]. Therefore, placing a proper land tenure policy which will enhance proper and sustainable development is also not a choice but a necessity for the sustained use of land in the country.

\subsection{Environmentally Conducive Land-Use Decisions}

As a result of geological variations, the nature and make up of land resources 
differs from place to place. Land situated in a specific area will only have its own capabilities which can only support its sustainability and if used beyond its potential, benefits will not last longer. It is because, a particular section of land surface will have its own qualities that can accommodate specific land-use options and may not be suitable to accommodate every interest. For instance, a flood plain around a river basin may not be used for the construction of heavy infrastructure; it may rather best suit for the establishment of recreational sites. With the current growing investment opportunities of the country, land resources such as lakes, rivers, and fertile soil resources can still being over exploited and these ecologically vital ecosystems will fail to support the natural functions that sustain the wellbeing of humanity on the face of the earth.

Abiyata Shalla Soda Ash Share Company as for instance, produces soda ash $\left(\mathrm{Na}_{2} \mathrm{CO}_{3}\right)$ from sodium bicarbonate $\left(\mathrm{NaHCO}_{3}\right)$ dissolved in the Abiyata lake water. This Lake forms part of the Abiyata Shalla National Park of Ethiopia and supports different bird species like flamingoes and other aquatic and terrestrial land forms. In the production process of soda ash by this company, the Abiyata Lake water has to evaporate first in large evaporation ponds so that the sodium bicarbonate will be left behind which will be decomposed in to sodium carbonate (soda ash), water and carbon dioxide [36].

The factory on average produces about 4500 tonnes of soda ash per annum that requires $150 \mathrm{~m}^{3} /$ tonne of water. This scale of production has decline in recent years as the water level of Lake Abaya fallen drastically and the shore lines receded by 3 kilometers from the pumping station of the factory. To enhance the production, the factory has also planned to make use of the nearest Lake Shalla (another ecologically important ecosystem of the park) [37]. This kind of land use decision will continue to negatively impact the ecology of the area that will have a regional and global contribution towards climate change.

Land-use and management decisions have to be taken from the perspectives of profitability and environmental/social considerations without compromising the sustainability of the environment and the survival needs of the local community.

The current land-use policy and strategies should, therefore, foresee the potential impacts on the wider and ultimate goal of achieving the sustainable development goals of the nation.

\section{Conclusion}

Although the need for improved and enhanced development of technologies and investment opening-ups are unquestionable, consideration of the environmental impact analysis of development trends is also equally important. In the case of Ethiopia, many of the current investment ventures are having a considerable impact on the precious land resources of the country. Therefore, as sustainable development is highly reliant on the efficient utilization of land resources, policy and decision makers have to consider and take the necessary corrective measures so as to avert the negative impacts of the current trends of investment development on the land-use practices of the country. 


\section{References}

[1] USAID (2016) Agriculture and Food Security in Ethiopia. Addis Ababa.

[2] Gezahegn, A., Steven, W. and Eleni, G. (2003) The State of Food Security and Agricultural Marketing in Ethiopia. Addis Ababa.

[3] Gebreselassie, S. (2006) Intensification of Smallholder Agriculture in Ethiopia: Options and Scenarios. Future Agricultures Consortium Secretariat at the University of Sussex, Brighton BN1 9RE UK.

[4] Getnet, T. (2015) Determinates of Farmers' Adoption Decisions of Improved Seed Variety in Dabat District, Ethiopia. International Journal of Technology Enhancements and Emerging Engineering Research, 3, 48-56.

[5] DHS (Demographic and Health Survey) (2012) Demographic and Health Survey of Ethiopia 2011. Central Statistical Agency, Addis Ababa.

[6] CSA (Central Statistical Agency) (2009) Statistical Abstract of Ethiopia. Addis Ababa.

[7] MOI (Ministry of Information) (2004) Facts about Ethiopia. Press and Audiovisual Department, Ministry of Information, Addis Ababa.

[8] Chartres, C. and Varma, S. (2009) Water Scarcity and Food Security. International Water Management Institute. Science in Parliament, 66, 34-46.

[9] EIC (Ethiopian Investment Commission) (2016). http://www.investethiopia.gov.et/

[10] WB (World Bank) (2004) Opportunities and Challenges for Developing High-Value Agricultural Exports in Ethiopia. Addis Ababa.

[11] Semunigus, A. (2015) Ethiopia's External Trade Performance in the Recent Past. 13 th International Conference on the Ethiopian Economy, Addis Ababa, 23-25 July 2015,.

[12] Enger, E. (2004) Environmental Science. University of San Francisco, San Francisco.

[13] Getachew, A. and Nuppenau, E.A. (2009) Channel Choice in the Ethiopian Banana Markets: A Transaction Cost Economics Perspective. Journal of Economic Theory, 3, 80-90.

[14] EHDA (Ethiopian Horticulture Development Agency) (2015). http://www.ehda.gov.et/

[15] Degytnu Tilahun, G. (2012) Socio-Economic and Environmental Impact of Floriculture Industry in Ethiopia. Ghent University (Belgium), Agrocampus Ouest (France), Humboldt University of Berlin (Germany), Slovak University of Agriculture in Nitra (Slovakia) and University of Pisa (Italy) in Collaboration with Wageningen University (The Netherlands).

[16] Allafrica (2006) Five Major Flower Firms to Abandon Naivasha for Ethiopia. http://allafrica.com/stories/200602210922.html

[17] Belwal, R. and Chala, M. (2008) Catalysts and Barriers to Cut Flower Export: A Case Study of Ethiopian Floriculture Industry. International Journal of Emerging Markets, 3, 216-235. https://doi.org/10.1108/17468800810862650

[18] David, T. (2002) The Bloom on the Rose, Looking into the Floriculture Industry. Environmental Health Perspectives, 110, 240-247.

Deininger, S., Sharp, K. and Yared, A. (2003) Destitution in Wollo, Ethiopia. IDS Research Report 55, Institute of Development Studies, Brighton.

[19] Henshaw, A. (2008) Lissan Magazine, Flower Farming Blooms in Ethiopia. Addis Ababa. http://lissanonline.com/blog/? $\mathrm{m}=200801$

[20] Henshaw, A. (2008) Flower Farming Blooms in Ethiopia. BBC Africa News. 
http://news.bbc.co.uk/2/hi/africa/5016834.stm

[21] Taddese, A. (2016) The Negative Impact of Foreign Direct Investment on People's Right to Food: Ethiopia's Horticulture/Floriculture Industry. Central European University, Budapest.

[22] Rahmato, D. (2011) Land to Investors: Large-Scale Land Transfers in Ethiopia. Forum for Social Studies, Addis Ababa.

[23] Srinivasan, S. (2014) Extension of Deforestation in Ethiopia: A Review. Department of Economics, Madawalabu University, Bale Robe.

[24] Gebrehiwot, K. (2003) Ecology and Management of Boswellia papyrifera (Del.) Hochst. Dry Forests in Tigray, Northern Ethiopia. Doctoral Dissertation, University of Göttingen, Göttingen.

[25] IUCN (1990) Ethiopia National Conservation Strategy. Vol. 1, Addis Ababa.

[26] EFAP (1994) Ethiopian Forestry Action Program. EFAP, Addis Ababa.

[27] EARO (2000) Forestry Research Strategic Plan. Ethiopian Agricultural Research Organization.

[28] Gebrehiwot, K. (1995) Scope for Enhancing Farm Productivity Through Improved Traditional Agroforestry Practices Using Native Species of Trees in Tigray, Northern Ethiopia. MSc Dissertation, University College of North Wales, Bangor.

[29] Untamed Path Adventures (2016) Benefits of Ecotourism. http://www.untamedpath.com/eco-tours/benefits-of-ecotourism.shtml

[30] USGCRP (2007) Land Use and Land Cover Change. Washington DC.

[31] Abebe, Z. (2011) Tannery Waste Water Management Problems in Ethiopia: The Case of Batu Tannery. Addis Ababa University, College of Development Studies. Addis Ababa.

[32] Metacalf and Eddy Inc. (1991) Wastewater Engineering: Treatment, Disposal and Reuse. 3rd Edition, McGraw-Hill, New York.

[33] Gebre, A.E., Demissie, H.F., Mengesha, S.T. and Segni, M.T. (2016) The Pollution Profile of Modjo River Due to Industrial Wastewater Discharge, in Modjo Town, Oromia, Ethiopia. Journal of Environmental \& Analytical Toxicology, 6, 363.

[34] Tessema, M. and Fekensa, T. (2015) Lake Chamo and Its Biodiversity at CrossRoads: Implications of Letting Business as Usual. Ethiopian Biodiversity Institute, Addis Ababa.

[35] Mekonnen, M. (Unpublished) Aquatic Ecosystems and Anthropogenic Threats: The Case of Lake Chamo, Ethiopia.

[36] Jansen, H., Hengsdijk, H., Legesse, D., Ayenew, T., Hellegers, P. and Spliethoff, P. (2007) Land and Water Resources Assessment in the Ethiopian Central Rift Valley. Alterrarapport 1587, Wageningen University, Wageningen.

[37] Raventós Vilalta, E. (2010) Water Resources Management in the Central Rift Valley of Ethiopia. MSc Thesis, Universitat Politecnica De Catalunya, Barcelona. 
Submit or recommend next manuscript to OALib Journal and we will provide best service for you:

- Publication frequency: Monthly

- 9 subject areas of science, technology and medicine

- Fair and rigorous peer-review system

- Fast publication process

- Article promotion in various social networking sites (LinkedIn, Facebook, Twitter, etc.)

- Maximum dissemination of your research work

Submit Your Paper Online: Click Here to Submit

Or Contact service@oalib.com 